\title{
GROWTH PERFORMANCE OF FISH REARED UNDER DIFFERENT DENSITIES IN SEMI-INTENSIVE AND EXTENSIVE EARTHEN PONDS
}

\section{Ibrahim M. Shaker Abed El-Fattah ${ }^{1}$, and Mohamed M. Abdel-Aal. ${ }^{2}$ \\ 1- Limnology Department and}

2- Aquaculture Department Central Laboratory for Aquaculture Research, Abbassa, Sharkia, Egypt.

Key words: polyculture, intensive, extensive, water quality, plankton, growth performance, tilapia, mullet, carp, catfish.

\section{ABSTRACT}

工 ffect of stocking density on fish performance has been investigated in Eearthen ponds over five months of growing period in a polyculture system including Nile tilapia, common carp, silver carp, mullet and African catfish. Experimental ponds have been allocated to various stocking rates of $1,1.25,1.5,1.75,10$ and $14 \mathrm{fish} / \mathrm{m}^{3}$. The treatments of 10 and $14 \mathrm{fish} / \mathrm{m}^{3}$ represented the semi-intensive system, while lower densities represented the extensive calture system. Fish in all treatments received $25 \%$ crude protein pelleted fish feed at a rate of $3 \%$ of body weight that was adjusted throughout the growing period. Feed was offered twice/day for five days/week. Water quality has been monitored monthly. The physico - chemical analysis showed two distinct sets of values for the extensive and the semi-intensive stocking densities concurred with for the main water quality parameters, whereas the values of $\mathrm{pH}$, E.C., salinity, alkalinity, hardness, total phosphorus and orthophosphate were significantly higher in extensive system than the semi-intensive one, while values of D.O, SD, $\mathrm{NH}_{3}, \mathrm{NO}_{2}, \mathrm{NO} 3$ were higher in the semiintensive system compared to the extensive system. Plankton communities expressed as Chlorophyll " $a$ " was significantly higher in the extensive ponds. Average production was significantly higher in semiintensive ponds compared to the extensive ponds. However, for the main fish species (Nile tilapia), the average weight as well as the daily gain did not vary among treatments, while there were some differences with regard to average weight for other species. There was no difference concerning the condition factor in all treatments for any of the tested species. The 
economic analysis revealed increases in variable costs as well as higher net returns as the stocking density increased. However, the rate of return to capital percentage has decreased with the increase of the stocking density. The overall analysis suggested the semi-intensive system to be the most profitable system.

\section{INTRODUCTION}

The polyculture as practiced in aquaculture via stocking of fish species of different food habits proved to be an important management tool in utilizing efficiently the natural food resources in fish pond. Synergistic interactions among fish species are manifested by higher growth and yield in polyculture than in monoculture (Karplus et al. 1996). The bases for these interactions are the increase of available food resources and the improvement of environmental conditions (Milstein, 1992).

Polyculture was first practiced in China more than a thousand years ago. It was extremely extensive, requiring little management, stocking several species at low density, often without application of feeds, and producing relatively low yield at low production costs (Lin, 1982). In semi-intensive farming systems, usually natural food is stimulated through the application of organic manures or chemical fertilizers, while feeds are supplied to supplement the available natural food. Aeration devices and automatic feeders have been incorporated into such system whenever possible. By definition, fish are stoked in the semi-intensive system at higher densities compared to that in the extensive ones, and thus, production costs as well as yields are expected to be much higher. In these systems, the supplemented organic wastes and feeds are utilized directly by the fish and also act as fertilizers for the heterotrophic and autotrophic food web. Under manuring and supplemental feeding, natural food still represents an important component of the overall food utilized by fish. The autotrophic path constitutes not only the food source of plankton filter feeding fish, like silver carp, but also provides $60-80 \%$ and $50 \%$ of tilapia and carp requirements, respectively. The fish growth can even be attributed to natural food developed on the pond bottom (karplus, 1996).

Semi-intensive ployculture and monoculture systems are widely used in fish culture in Egypt, practiced in shallow earthen ponds and in deep dual-purpose irrigation reservoirs. The main species cultured in commercial ponds are Nile tilapia, Orechromis niloticus, common carp 
Cyprinus carpio, silver carp, Hypophthalmichtys molitrix, stripped mullet, Mugil cephalus and grey mullet, Liza ramada. These species are stocked in variety of combinations. The outcomes of such system as fish biomass vary widely.

Recently, along with the intensification trend in Egyptian aquaculture, the requirement for high quality feed has increased. Such higher production costs as well as the high investments have called for better management practices. The contribution of feed costs in fish production increases along with the level of intensification, reaching the highest component in farm operation (Islam, 2002). From economic point of view, such practices may not suite the small-scale farmers with little resources whether in the tropics and to some extent in some parts of Egypt. This is due to financial constraints which limit the ability of those farmers from accessing the commercially produced pelleted feeds. Thus, in order for those farms to utilize easy to find feed at low cost, alternative management strategies are required.

Fish stocking density is a key factor in determining the management of fish pond and so, the production. It affects the amounts of natural food available per fish, the level of supplemented feeding required (Hepher, 1988), and thus, the intensity of inter- and intra-specific food competition. With increasing stocking density, competition for food among fish increases. The optimal combined stocking densities of several species of fish cultured together should be carefully analyzed in order to optimize both fish performance (growth and yield) and economic profitability of the combined system. Therefore, the objectives of the present study are to evaluate fish production and growth performance as well as the grow-out environments under different stocking densities of fish cultured. Economical evaluation for farming systems tested was a main element in the study. Finally, the study tackled the issue of the use of drainage water in Egyptian fish farming.

\section{MATERIALS AND METHODS}

The present study was conducted in earthen ponds; including six ponds of 4,200 $\mathrm{m}^{2}$ surface area - each and twelve ponds of 54,600 $\mathrm{m}^{2}$ surface area each. Ponds were located at Manzala fish farm, Manzala, Egypt. The first six ponds had $1.5 \mathrm{~m}$ as an average water depth, while the twelve ponds had an average water depth of $1.25 \mathrm{~m}$. Aeration devices were used in the six ponds (2 Impeller Paddle wheel Aerator-AR-A232-2 h), while, no aeration was practiced in the twelve ponds. Fish were 
stocked on in May and harvested in 20 October 2005 after about 150 days of growth period. Each treatment was conduced in three replicates.

The present study consisted of two parts, which were conducted in completely randomized design. The first group was used to evaluate the fish stocking density under the semi-intensive system at a rate of 10 and $14 \mathrm{fish} / \mathrm{m}^{3}$. The second part of the study was targeted to evaluate the lower stocking density used in the extensive system, where the rate of 1 , 1.2, 1.5 and $1.7 \mathrm{fish} / \mathrm{m}^{3}$ have been used as shown in Table 1 . The two systems had been stocked with the same fish species, namely, Nile tilapia, (Oreochromis niloticus); common carp, (Cyprinus carpio), silver carp, (Hypophthalmichtys molitrix), mullet, (Mugil cephalus) and catfish, (Clarias gariepinus). Commercial feed pellets (25\% crude protein) was used throughout the experiment and was provided twice a day; five days a week at a rate of $3 \%$ of body weight and automatically and manually distributed for the semi-intensive and extensive fish ponds, respectively. All experimental ponds were fertilized using poultry liter (150 $\mathrm{kg} /$ Fadden $^{1}$ ). Thereafter, ponds were filled with water for no longer than two weeks before fish stocking. Fish sampling for all species was carried out monthly and the amount of feed was adjusted accordingly.

Water sampling was carried out for several parameters of concern to aquaculture. Physico-chemical parameters were monitored monthly. Temperature and dissolved oxygen were determined directly by a portable digital oxygen meter (YSI model 58, USA), $\mathrm{pH}$ was measured using a digital $\mathrm{pH}$ meter (Accumet 340) and transparency by a Secchhi disc. Water electrical conductivity and salinity were determined by conductivity meter (Orion 630), Nitrate, nitrite and free ammonia were determined using a HACH water analysis kits (DR 2000, USA), while total phosphorus, orthophosphate, total alkalinity, total hardness, chlorophyll " $a$ " were determined according to standard methods (APHA, 2000) 100ml water sample was filtered through $0.45 \mathrm{M}$ Millipore filter and chlorophyll $a$ was extracted in $5 \mathrm{ml}$ of $90 \%$ acetone and grinded by tissue grinder, kept for $24 \mathrm{~h}$ at $5^{\circ} \mathrm{C}$.The sample was then centrifuged and measured the absorbance of acetone, chlorophyll $a$ concentration was calculated using the equation:

Chlorophyll a in $\mu g=11.9($ A665-A750) V/Lx1000/s

Where: A665 = the absorbance at $665 \mathrm{~A}, \mathrm{~A} 750$ the absorbance at $750, \mathrm{~V}=$ the acetone extract in $\mathrm{ml}, \mathrm{L}=$ the length path in the spectrophotometer in $\mathrm{cm}, \mathrm{S}=$ the volume in $\mathrm{ml}$ of sample filtered.

${ }^{1}$ Fadden $=4200 \mathrm{~m}^{2}$ 
Qualitative and quantitative estimates of phytoplankton and zooplankton were also recorded monthly. The analyses of heavy metals in water and different fish species were determined using atomic absorption (Thermo 6500,) with graphite furnace according to APHA (2000). At the end of the experiment, fish were harvested, counted and weighed. The growth parameters were calculated as follows:

Daily gain $(D G)=\left(\mathrm{Wt}_{2}-\mathrm{Wt}_{1}\right) / \mathrm{T}$; Specific growth rate $(\mathrm{SGR})=\left(\mathrm{Ln} \mathrm{Wt}_{2}\right.$ - $\mathrm{Wt}_{1}$ ) $\times 100 / \mathrm{T}$; where $\mathrm{Wt}_{1}$ is the initial weight in grams, $\mathrm{Wt}_{2}$ is the second weight in grams, and $\mathrm{T}$ is the period in days Condition factor $(\mathrm{K})$ $=$ Body weight $/$ Total length ${ }^{3}$ x 100.

Statistical analysis was performed using the analysis of variance (ANOVA). Duncan's Multiple Range Test Duncan (1955) was used to determine the significant differences between means at $\mathrm{P}<0.05$. Standard errors of treatment means were also estimated. All statistical evaluations were carried out using Statistical Analysis Systems (SAS) program (SAS, 2000) according to Steel and Torrie (1960).

\section{RESULTS AND DISCUSSION}

The results of physico-chemical parameters and the selected heavy metals in water under different experimental treatments are shown in Tables (2 and 3). The $\mathrm{pH}$ values in pond water of the treatments ranged from 8.45 to 9.6. This variation could be explained by the photosynthetic uptake of $\mathrm{CO}_{2}$ and bicarbonate that substituted hydroxyl ions. The $\mathrm{pH}$ values in extensive ponds were not significantly different. These results indicate that the increase of fish density from 1.0 to $1.75 \mathrm{fish} / \mathrm{m}^{3}$ did not affect $\mathrm{pH}$ values $(\mathrm{P}>0.05)$. This result is in agreement with Shaker et al. (2002). However, the increase in fish density from 1.75 to $14 \mathrm{fish} / \mathrm{m}^{3}$ has significantly affected the $\mathrm{pH}$ values indicating that they decreased significantly with the increase in stocking density the $\mathrm{pH}$ values increased by several folds in the semi-intensive system compared to that in the extensive one. Dissolved oxygen (DO mg/l) concentration ranged from 4.3 to $6.9 \mathrm{mg} / \mathrm{l}$ in all treatments. DO concentrations in extensive ponds did not vary significantly, while the difference was significant between semi - intensive ponds and others. The use of paddle wheel in semiintensive ponds enhanced significantly $(\mathrm{p}<0.05)$ the DO concentrations in ponds furnished by those aerators compared to the rest of the ponds. Results of Table (2) revealed that differences among the applied treatments in averages of water temperature were insignificant and ranged between 27.1 and $27.5^{\circ} \mathrm{C}$. The $\mathrm{pH}$, temperature and dissolved oxygen 
were the most influencing parameters in fish ponds, where their values in all ponds although fluctuated from time, to time they stayed within the acceptable and favorable levels required for growth, survival and well being of the tested fish species.

The SD readings were higher in the semi-intensive ponds indicating the low abundance of plankton in these ponds compared to the extensive cultured ponds. These results are in agreement with those obtained by Shaker et al. (2002).

The average levels of ammonia-nitrogen were $2.5 ; 2.7 ; 1.3 ; 1.4$; 1.5 and $1.6 \mathrm{mg} / \mathrm{l}$ for semi-intensive treatments $(1,2)$ and extensive treatments (3-6), respectively. The concentrations of the un-ionized ammonia (toxic form) $\mathrm{NH}_{3}-\mathrm{N}$ in the present study was lower than those recorded in fertilized fish ponds at Lake Burullus (Mosua, 2004). The increase of $\mathrm{NH}_{3}-\mathrm{N}$ in the semi-intensive ponds compared to other treatments could be explained by the decomposition of organic matter and via the direct excretion of ammonia by the large biomass of fish. The $\mathrm{NO}_{2}$ and $\mathrm{NO}_{3}$ concentrations in water followed the same trend of ammonianitrogen. The concentrations of $\mathrm{NO}_{2}$ and $\mathrm{NO}_{3}$ were also higher in semiintensive treatments. These results may be due to the consumption of nitrate (which is an essential nutrient) by phytoplankton communities in treatments 3-6. Also, the increase of nitrate in semi-intensive treatments may be related to the decrease of phytoplankton standing corps. It is of particular interest to notice a negative correlation between nitrate content and total phytoplankton which may be attributed to high consumption rate of $\mathrm{NO}_{3}-\mathrm{N}$ by the dense vegetation. These results are in harmony with those obtained by Shaker et al. (2002); Islam (2002) and Mousa (2004). The average concentrations of total alkalinity (T. alk.) and total hardness (T.H) were suitable for fish growth, survival and well being. These results are in agreement with those obtained by Mousa (2004). The average concentrations of total phosphorus (T.P) and orthophosphate (O.P) were lesser in semi-intensive than in the other treatments. These results may be due to the water exchange in semi-intensive pond that led to the decrease of organic matter in these ponds. The average concentration of chlorophyll " $a$ " increased with decreasing fish density per $\mathrm{m}^{3}$.

Iron, manganese, zinc, copper, lead, cadmium and mercury were detected monthly during the experimental period in all ponds (Table 3). While the average concentration of mercury did not vary significantly among treatments, these of $\mathrm{Fe}, \mathrm{Mn}, \mathrm{Zn}, \mathrm{Cu}$ and $\mathrm{Pb}$ varied significantly between semi-intensive ponds and other ponds. It is worthy to mention 
that the mean concentrations of heavy metals stayed within the safety range established for aquaculture by FAO ( 2001 ), WHO ( 1989 ) and Mancy ( 1993 ).

Heavy metals concentrations in fish organs are presented in Table (4).The highest levels were found in liver, followed by gills and then muscles in semi-intensive and extensive ponds. These metal concentrations were accumulated from the blood system of fish. In this connection, Shereif and Moaty (1995) found that heavy metals were significantly higher in fish viscera, including liver tissue than in the edible muscles. On the other hand, the highest accumulation of heavy metals in fish species was found in mullet followed by common carp then Nile tilapia and silver carp (Table 4). Generally, it is found that the accumulation level of heavy metals of the present fish species was within the permissible legal limits for different countries (USEPA, 1986 ; WHO, 1989). For example, in the United Kingdom the legal limits for $\mathrm{Zn}$ and $\mathrm{Pb}$ in fishery products are 50 and 2-10 $\mu \mathrm{g} / \mathrm{g}$, respectively; in Australia it is 40 $\mu \mathrm{g} / \mathrm{g}$ for $\mathrm{Zn}$ and 1.5-5.5 $\mu \mathrm{g} / \mathrm{g}$ for $\mathrm{Pb}$ (Nauen, 1983), while the WHO guidelines sets the limits as $1000 \mu \mathrm{g} / \mathrm{g}$ for $\mathrm{Zn}$ and $2.0 \mu \mathrm{g} / \mathrm{g}$ for $\mathrm{Pb}$ (WHO, 1989). Mosua (2004) recorded concentration levels of iron, zinc, cadmium and lead as 12.2, 30.0, 0.5 and $5.2 \mu \mathrm{g} / \mathrm{g}$ respectively in Nile tilapia in Lake Burullus. However, Noble (1975), Turner et al. (1986) and Edwards (1992) stated that there may not be a substantial public health problem produced by the bioaccumulation of toxic elements because almost all organisms contained levels of contaminants, which are below Egyptian National Legal Limits.

As presented in Table (5), the average numbers of phytoplankton and zooplankton decreased with the increase of fish stocking density. The average number of phytoplankton and zooplankton in semi-intensive were 2280 and 99; and 6773 and 380.5 org. /l in extensive ponds, respectively. These results clearly demonstrate that the total amount of phytoplankton and zooplankton decreased in semi-intensive ponds compared to extensive ponds. These results are in agreement with those obtained by Shaker (2002). Semi-intensive farming is usually based solely on artificial feed, while extensive system depends on natural food supplemented by artificial feed which in turn decreases the production cost per kg of fish in the extensive system. Generally, there were positive correlation among total phosphors (T.P); ortho phosphate (O.P); chlorophyll " $a$ " and plankton community and inverse correlation with SD reading in fish 
ponds. Chlorophyll " $a$ " contents in water ponds were related to the occurrence of phytoplankton in ponds water.

Fish production and growth performance parameters are illustrated in Tables (6 \& 7). The average final weights of Nile tilapia were 216 and 194.25 g for semi-intensive and extensive ponds. Respectively. It is clear that the average weights of Nile tilapia and mullets were higher in semiintensive system than in extensive treatments. This may be due to the use of artificial feed as the only nutritional source in the semi-intensive system and both species were able to utilize it efficiently. In the natural food medium that supplemented by artificial feed in extensive system, silver carp, common carp and catfish were able to utilize natural communities better and so attaining higher growth rates in extensive treatments than in semi-intensive ones. The average of total fish production for all treatments were $10.374 ; 13.911 ; 1.743 .5 ; 2.042 .5$; 2.142 .5 and $2.286 .5 \mathrm{~kg} /$ feddan for $10 ; 14 ; 1.0 ; 1.26 ; 1.5$ and $1.7 \mathrm{fish} / \mathrm{m}^{3}$ treatments, respectively. These results clearly demonstrate the positive correlation between fish production and stocking density. These findings agree with those obtained by Shaker et al. (2002), Sumagaysay and Lourdes (2003) and Yang Yi et al. (2003) who found that phytoplankton based food chain was relatively unimportant in pond culture that relies on artificial feed to promote fish growth.

From the data presented in Table (7), it is clear that the daily gain of catfish was higher than other fish species as silver carp, common carp, mullet and Nile tilapia. Also, the daily gain of different fish species was higher in extensive ponds than semi-intensive ponds. These results indicated that the daily gain for each species was negatively correlated with stocking density. Moreover, the same trend was observed in the specific growth rate (SGR). These results are in agreement with those obtained by Karplus et al. (1996) and Yang Yi et al. (2003). The condition factor did not vary among all species in all treatments ( $\mathrm{P}$ $<0.05$ ).

The economical analysis in the present study is presented in Table (9) and the comparison between semi-intensive and extensive treatments is presented in Table (8).The total values of total return per Fadden were 62.491; 82.809; 9.670; 11.832.5; 12.822 and 14.184.5 LE for T1; T2; T3; T4; T5 and T6. respectively. These results indicated that the highest total return was obtained in semi-intensive treatments. As well as in treatment 2 , these indicating a positive correlation between total return and stocking density. Also, the same trend was observed in total costs, where they 
increased with increasing stocking density and consequently feed costs. The finding of Shaker et al. (2003) and Yang Yi et al. (2003) are in agreement with obtained results. Moreover, the same trend was observed by the average cost $/ \mathrm{kg}$ fish, while the opposite trend was observed in the rate of return to capital as percentage.

\section{REFERENCES}

American Public Health Association (APHA), (2000). Standard Methods for the Examination of Water and Wastewater. The $16^{\text {th }}$ edition, Washington, D. C.

Edwards, P. (1992). Reuse of human wastes in aquaculture. A technical review. UNEP-World Blank \& Sanitation program. The World Blank, Washington DC, USA.

Food and Agriculture Organization of the United Nations (FAO) (1999). The state of the world fisheries and aquaculture 1998. FAO. Rome, Italy.

Food and Agriculture Organization of the United Nations (FAO) (2001). Summary tables of fishery statistics; world aquaculture production by principal species. http://www.fao.org/fi/statist/summtab/ fault. asp

Hepher, B. (1988). Nutrition of pond fishes. Cambridge University press. Cambridge.

Islam, S. M.. (2002). Evaluation of supplementary feeds for semiintensive pond culture of mahseer, Tor putitora (Hamilton). Aqua., 212: 263-276.

Karplus, I.; Milstein, A.; Cohen, S. and Harpaz, S. (1996). The effect of stocking different ratios of common carp, Cyprinus carpio L., and tilapias in polyculture ponds on production characteristics and profitability. Aqua. Res., 27: 447-453.

Lin, H.R. (1982). Polyculture system of freshwater fish in China. Canadian Journal of Fisheries and Aquatic Sci., 39: 143-150. 
Milstein, A. (1992). Ecological aspects of fish species interactions in polyculture ponds. Hydrobio., 231: 177-186.

Mancy, K.H. (1993). Wastewater treatment at Suez experimental station progress report. National Institute of Oceanography and Fisheries.

Moussa, S. M. S. (2004). Impact of inorganic pollutants on aquatic environment and fish performance in lake Borollus. Ph. D. Thesis, Inst. of Environment Stud. and Res., Biol. \& Phys. Dep., Ain hams Univ., Egypt.

Noble, R. (1975). Growing fish in sewage. New Sci. 67: 259-261.

Nauen, C. E. (1983). Compilation of legal limits for hazardous substances in fish and fishery products. FAO Fisheries Circular No. 764., Rome, Italy, pp.

Shaker, I. M. A.; El-Nagdy, Z. A and Ibrahim, N. A. (2003). Effect of organic manure and artificial feeding on water quality and growth performance on Mullet in earthen ponds in Sahl El-teena, Sinai, Egypt. The 1st Scientific conference of the Egyptian Aquaculture Society, Fac. of Environ. Agric. Sci., El-Arish, North Sinai, Egypt, 13-15 Dec. pp.77-96.

Shaker, I. M. A.; Ibrahim, N. A.; Dawa, M. A. A. and Zakar, A. H. (2002).Effect of stocking density on water quality and mullet growth in earthen ponds at Sahl El-Teena - Senai - Egypt. The $6^{\text {th }}$ Vet. Med. Zagazig. Conference, 7-9 Sept. 2002, Hurghada, Egypt, pp.

Shereif, M.M. and Moaty, M.A.(1995). Concentration levels and accumulation metals in Nile tilapia grown in wastewater fed fish ponds. In the second Middle East Conference for Waste Management Cairo Publications. Egypt. pp. 284-298.

Statistical Analysis System (SAS) (2000). SAS program Ver 6.12, SAS Institute Incorporation, Cary, NC 27513, USA.

Steel, R.G.D and Torrie, J.H (1960). Principles and procedures of statistics. McGraw-Hill Co., New York. 
Sumagaysay, C. N. S. and Lourdes, S. D. M. (2003). Water quality and holding capacity of intensive and semi-intensive milk fish (Chanos chanos) ponds. Aqua., 219: 413-429.

Turner, J.W.D.; Sibbald, R.R. and Hemens, J. (1986). Chlorinate secondary domestic effluent as a fertilizer for marine aquaculture. 3- Assessment of bacterial and viral quality and accumulation of heavy metals. Aqua., 53: 157-168.

U. S. E. P. A. (Environmental Protection Agency (1986). Quality Criteria for Water. 44015-86-001 Washington.

WHO (1989). Health guidelines for the use of the wastewater in agriculture and aquaculture. WHO Technical Report Series, No. 778., World Health Organization, Geneva.

Yang Yi; Kwei, C. L. and Diana, J. S. (2003). Hybrid Catfish (Clarias macrocephalus x C. gariepinus) and Nile tilapia (Oreochromis niloticus) culture in an integrated pen-cum pond system: growth performance and nutrient budgets. Aqua., 217: 395-408. 
Table(1): Stocking fish number and weight for different fish species in experimental ponds.

\begin{tabular}{|c|c|c|c|c|c|c|c|c|c|c|c|c|c|c|c|c|c|c|}
\hline Fish & & e Tila & & & $\mathrm{Mul}$ & & & mon & & & ver $\mathrm{C}$ & & & Catf & & & & \\
\hline Treat & No. & $\begin{array}{c}\text { I.W } \\
\mathrm{g}\end{array}$ & $\begin{array}{c}\text { T.w } \\
\text { kg }\end{array}$ & No. & $\begin{array}{c}\text { I.W } \\
\mathrm{g}\end{array}$ & $\begin{array}{c}\text { T.w } \\
\text { kg }\end{array}$ & No. & $\begin{array}{c}\text { I.W } \\
\mathrm{g}\end{array}$ & $\begin{array}{c}\text { T.w } \\
\text { kg }\end{array}$ & No. & $\begin{array}{c}\text { I.W } \\
\mathrm{g}\end{array}$ & $\begin{array}{c}\text { T.w } \\
\text { kg }\end{array}$ & No. & $\begin{array}{c}\text { I.W } \\
\mathrm{g}\end{array}$ & $\begin{array}{c}\text { T.w } \\
\mathrm{kg}\end{array}$ & No. & T.w & $\begin{array}{c}\text { fish } \\
\text { per- } \\
\text { m3 }\end{array}$ \\
\hline 1 & 39550 & $\begin{array}{c}40 \\
\pm \\
5.0\end{array}$ & $\begin{array}{c}1582 \\
\pm \\
15.75\end{array}$ & 2000 & $\begin{array}{c}50 \\
\pm \\
3.0\end{array}$ & $\begin{array}{c}100 \\
\pm \\
5.5\end{array}$ & 600 & $\begin{array}{c}50 \\
\pm \\
3.0\end{array}$ & $\begin{array}{c}30.0 \\
\pm \\
1.2\end{array}$ & 200 & $\begin{array}{c}50 \\
\pm \\
5.0\end{array}$ & $\begin{array}{c}10.0 \\
\pm \\
0.7\end{array}$ & 200 & $\begin{array}{c}50 \\
\pm \\
5.0\end{array}$ & $\begin{array}{c}10.0 \\
\pm \\
0.5\end{array}$ & $\begin{array}{c}4255 \\
0\end{array}$ & $\begin{array}{c}1732 \\
\pm \\
31.5\end{array}$ & 10.1 \\
\hline 2 & 55050 & $\begin{array}{c}40 \\
\pm \\
5.0\end{array}$ & $\begin{array}{c}2202 \\
\pm \\
16.65\end{array}$ & 3000 & $\begin{array}{c}50 \\
\pm \\
3.0\end{array}$ & $\begin{array}{c}150 \\
\pm \\
6.5\end{array}$ & 800 & $\begin{array}{c}50 \\
\pm \\
5.0\end{array}$ & $\begin{array}{c}40.0 \\
\pm \\
1.3\end{array}$ & 200 & $\begin{array}{c}50 \\
\pm \\
5.0\end{array}$ & $\begin{array}{c}10.0 \\
\pm \\
0.7\end{array}$ & 200 & $\begin{array}{c}50 \\
\pm \\
5.0\end{array}$ & $\begin{array}{c}10.0 \\
\pm \\
0.5\end{array}$ & $\begin{array}{c}5905 \\
0\end{array}$ & $\begin{array}{c}2412 \\
\pm \\
35.5\end{array}$ & 14.1 \\
\hline 3 & 3525 & $\begin{array}{c}10 \\
\pm \\
2.0\end{array}$ & $\begin{array}{c}35.25 \\
\pm \\
3.4\end{array}$ & 250 & $\begin{array}{c}20 \\
\pm \\
1.5\end{array}$ & $\begin{array}{c}5.0 \\
\pm \\
0.4\end{array}$ & 125 & $\begin{array}{c}30 \\
\pm \\
3.0\end{array}$ & $\begin{array}{c}3.75 \\
\pm \\
0.2\end{array}$ & 200 & $\begin{array}{c}50 \\
\pm \\
5.0\end{array}$ & $\begin{array}{c}10.0 \\
\pm \\
0.7\end{array}$ & 200 & $\begin{array}{c}50 \\
\pm \\
5.0\end{array}$ & $\begin{array}{c}10.0 \\
\pm \\
0.5\end{array}$ & 4200 & $\begin{array}{c}64.0 \\
\pm \\
3.2\end{array}$ & 1.0 \\
\hline 4 & 3875 & $\begin{array}{c}10 \\
\pm \\
2.0\end{array}$ & $\begin{array}{c}38.75 \\
\pm \\
3.4\end{array}$ & 750 & $\begin{array}{c}20 \\
\pm \\
1.5\end{array}$ & $\begin{array}{c}15.0 \\
\pm \\
0.75\end{array}$ & 400 & $\begin{array}{c}30 \\
\pm \\
3.0\end{array}$ & $\begin{array}{c}12.0 \\
\pm \\
0.5\end{array}$ & 200 & $\begin{array}{c}50 \\
\pm \\
5.0\end{array}$ & $\begin{array}{c}10.0 \\
\pm \\
0.7\end{array}$ & 200 & $\begin{array}{c}50 \\
\pm \\
5.0\end{array}$ & $\begin{array}{c}10.0 \\
\pm \\
0.5\end{array}$ & 5325 & $\begin{array}{c}85.75 \\
\pm \\
3.4\end{array}$ & 1.268 \\
\hline 5 & 4434 & $\begin{array}{c}10 \\
\pm \\
2.0\end{array}$ & $\begin{array}{c}44.34 \\
\pm \\
3.55\end{array}$ & 1250 & $\begin{array}{c}20 \\
\pm \\
1.5\end{array}$ & $\begin{array}{c}25.0 \\
\pm \\
1.1\end{array}$ & 400 & $\begin{array}{c}30 \\
\pm \\
3.0\end{array}$ & $\begin{array}{c}12.0 \\
\pm \\
0.5\end{array}$ & 200 & $\begin{array}{c}50 \\
\pm \\
5.0\end{array}$ & $\begin{array}{c}10.0 \\
\pm \\
0.7\end{array}$ & 200 & $\begin{array}{c}50 \\
\pm \\
5.0\end{array}$ & $\begin{array}{c}10.0 \\
\pm \\
0.5\end{array}$ & 6384 & $\begin{array}{c}101.3 \\
4 \\
\pm \\
3.44\end{array}$ & 1.52 \\
\hline 6 & 4575 & $\begin{array}{c}10 \\
\pm \\
2.0\end{array}$ & $\begin{array}{c}45.75 \\
\pm \\
3.75\end{array}$ & 1750 & $\begin{array}{c}20 \\
\pm \\
1.5\end{array}$ & $\begin{array}{c}35.0 \\
\pm \\
1.2\end{array}$ & 800 & $\begin{array}{c}30 \\
\pm \\
3.0\end{array}$ & $\begin{array}{c}24.0 \\
\pm \\
0.75\end{array}$ & 200 & $\begin{array}{c}50 \\
\pm \\
5.0\end{array}$ & $\begin{array}{c}10.0 \\
\pm \\
0.7\end{array}$ & 200 & $\begin{array}{c}50 \\
\pm \\
5.0\end{array}$ & $\begin{array}{c}10.0 \\
\pm \\
0.5\end{array}$ & 7425 & $\begin{array}{c}124.7 \\
5 \\
\pm \\
5.5\end{array}$ & 1.77 \\
\hline
\end{tabular}


Table (2): Total annual means of some physico-chemical characteristics of water samples on experimental ponds.

\begin{tabular}{|c|c|c|c|c|c|c|c|c|c|c|c|c|c|c|c|c|c|}
\hline $\begin{array}{l}\text { Xtems } \\
\text { Treat. }\end{array}$ & $\begin{array}{l}\text { Density } \\
\text { Fish/ } \mathrm{m}^{3}\end{array}$ & $\begin{array}{l}\text { Temp. } \\
{ }^{\circ} \mathrm{C}\end{array}$ & $\mathrm{pH}$ & $\begin{array}{l}\text { D. O } \\
\text { mg/l }\end{array}$ & $\begin{array}{l}\text { Satura. } \\
\%\end{array}$ & $\begin{array}{l}\mathrm{SD} \\
\mathrm{Cm}\end{array}$ & $\begin{array}{l}\mathrm{NH}_{3} \\
\mathrm{mg} / \mathrm{l}\end{array}$ & $\begin{array}{l}\mathrm{NO}_{2} \\
\mathrm{mg} / \mathrm{l}\end{array}$ & $\begin{array}{l}\mathrm{NO}_{3} \\
\mathrm{mg} / \mathrm{l}\end{array}$ & $\begin{array}{l}\text { T. N } \\
\mathrm{mg} / \mathrm{l}\end{array}$ & $\begin{array}{l}\text { E. C } \\
\text { mmhos/Cm }\end{array}$ & $\begin{array}{l}\text { Salinity } \\
\text { g/l }\end{array}$ & $\begin{array}{l}\text { T. alk } \\
\mathrm{mg} / \mathrm{l}\end{array}$ & $\begin{array}{l}\text { T. H } \\
\mathrm{mg} / \mathrm{l}\end{array}$ & $\begin{array}{l}\text { T. P } \\
\mathrm{mg} / \mathrm{l}\end{array}$ & $\begin{array}{l}\mathrm{O} . \mathrm{P} \\
\mathrm{mg} / \mathrm{l}\end{array}$ & $\begin{array}{l}\text { Chlorophyll } \\
\text { "a" } \\
\mu \mathrm{g} / \mathrm{l}\end{array}$ \\
\hline 1 & 10.1 & $\begin{array}{l}27.5 \\
\pm \\
1.1 \mathrm{a}\end{array}$ & $\begin{array}{l}8.6 \\
\pm \\
0.9 \mathrm{~b}\end{array}$ & $\begin{array}{l}6.7 \\
\pm \\
1.0 \mathrm{a}\end{array}$ & $\begin{array}{l}82.5 \\
\pm \\
5.5 \mathrm{a}\end{array}$ & $\begin{array}{l}25.5 \\
\pm \\
2.5 \mathrm{a}\end{array}$ & $\begin{array}{l}2.5 \\
\pm \\
0.4 \mathrm{a}\end{array}$ & $\begin{array}{l}0.37 \\
\pm \\
0.12 \mathrm{~b}\end{array}$ & $\begin{array}{l}0.36 \\
\pm \\
0.1 \mathrm{~b}\end{array}$ & $\begin{array}{l}5.5 \\
\pm \\
1.6 \mathrm{a}\end{array}$ & $\begin{array}{l}2.5 \\
\pm \\
0.3 \mathrm{~b}\end{array}$ & $\begin{array}{l}2.0 \\
\pm \\
0.1 \mathrm{~b}\end{array}$ & $\begin{array}{l}290 \\
\pm \\
50 \mathrm{~b}\end{array}$ & $\begin{array}{l}410 \\
\pm \\
72 \mathrm{~b}\end{array}$ & $\begin{array}{l}0.92 \\
\pm \\
0.06 \mathrm{~b}\end{array}$ & $\begin{array}{l}0.32 \\
\pm \\
0.06 \mathrm{~b}\end{array}$ & $\begin{array}{l}24.5 \\
\pm \\
4.6 \mathrm{~b}\end{array}$ \\
\hline 2 & 14.1 & $\begin{array}{l}27.4 \\
\pm \\
0.7 \mathrm{a}\end{array}$ & $\begin{array}{l}8.45 \\
\pm \\
1.0 \mathrm{~b}\end{array}$ & $\begin{array}{l}6.9 \\
\pm \\
1.0 \mathrm{a}\end{array}$ & $\begin{array}{l}86.1 \\
\pm \\
5.1 \mathrm{a}\end{array}$ & $\begin{array}{l}27.5 \\
\pm \\
3.5 \mathrm{a}\end{array}$ & $\begin{array}{l}2.7 \\
\pm \\
0.6 \mathrm{a}\end{array}$ & $\begin{array}{l}0.46 \\
\pm \\
0.11\end{array}$ & $\begin{array}{l}0.42 \\
\pm \\
0.12 \mathrm{a}\end{array}$ & $\begin{array}{l}5.9 \\
\pm \\
1.8 \mathrm{a}\end{array}$ & $\begin{array}{l}2.5 \\
\pm \\
0.2 \mathrm{~b}\end{array}$ & $\begin{array}{l}1.9 \\
\pm \\
0.1 \mathrm{~b}\end{array}$ & $\begin{array}{l}295 \\
\pm \\
42 \mathrm{~b}\end{array}$ & $\begin{array}{l}435 \\
\pm \\
70 \mathrm{~b}\end{array}$ & $\begin{array}{l}0.96 \\
\pm \\
0.14 \mathrm{~b}\end{array}$ & $\begin{array}{l}0.34 \\
\pm \\
0.07 \mathrm{~b}\end{array}$ & $\begin{array}{l}27.5 \\
\pm \\
3.1 \mathrm{~b}\end{array}$ \\
\hline 3 & 1 & $\begin{array}{l}27.1 \\
\pm \\
0.6 \mathrm{a}\end{array}$ & $\begin{array}{l}9.5 \\
\pm \\
1.1 \mathrm{a}\end{array}$ & $\begin{array}{l}4.3 \\
\pm \\
0.5 \mathrm{~b}\end{array}$ & $\begin{array}{l}65.7 \\
\pm \\
3.5 \mathrm{~b}\end{array}$ & $\begin{array}{l}10.5 \\
\pm \\
1.0 \mathrm{~b}\end{array}$ & $\begin{array}{l}1.3 \\
\pm \\
0.4 \mathrm{~b}\end{array}$ & $\begin{array}{l}0.12 \\
\pm \\
0.03 \mathrm{c}\end{array}$ & $\begin{array}{l}0.16 \\
\pm \\
0.05 c\end{array}$ & $\begin{array}{l}3.3 \\
\pm \\
1.1 \mathrm{~b}\end{array}$ & $\begin{array}{l}3.3 \\
\pm \\
0.3 \mathrm{a}\end{array}$ & $\begin{array}{l}2.6 \\
\pm \\
0.1 \mathrm{a}\end{array}$ & $\begin{array}{l}375 \\
\pm \\
64 \mathrm{a}\end{array}$ & $\begin{array}{l}485 \\
\pm \\
56 \mathrm{a}\end{array}$ & $\begin{array}{l}1.56 \\
\pm \\
0.24 a\end{array}$ & $\begin{array}{l}0.76 \\
\pm \\
0.11 \mathrm{a}\end{array}$ & $\begin{array}{l}114.6 \\
\pm \\
12.6 \mathrm{a}\end{array}$ \\
\hline 4 & 1.268 & $\begin{array}{l}27.2 \\
\pm \\
0.8 \mathrm{a} \\
\end{array}$ & $\begin{array}{l}9.6 \\
\pm \\
0.9 \mathrm{a} \\
\end{array}$ & $\begin{array}{l}4.5 \\
\pm \\
0.5 \mathrm{~b} \\
\end{array}$ & $\begin{array}{l}66.4 \\
\pm \\
6.5 \mathrm{~b}\end{array}$ & $\begin{array}{l}12.0 \\
\pm \\
1.0 \mathrm{~b} \\
\end{array}$ & $\begin{array}{l}1.4 \\
\pm \\
0.5 \mathrm{~b} \\
\end{array}$ & $\begin{array}{l}0.14 \\
\pm \\
0.04 \mathrm{c}\end{array}$ & $\begin{array}{l}0.16 \\
\pm \\
0.05 \mathrm{c} \\
\end{array}$ & $\begin{array}{l}3.25 \\
\pm \\
0.9 \mathrm{~b} \\
\end{array}$ & $\begin{array}{l}3.2 \\
\pm \\
0.3 \mathrm{a} \\
\end{array}$ & $\begin{array}{l}2.6 \\
\pm \\
0.1 \mathrm{a}\end{array}$ & $\begin{array}{l}380 \\
\pm \\
60 \mathrm{a} \\
\end{array}$ & $\begin{array}{l}486 \\
\pm \\
66 \mathrm{a} \\
\end{array}$ & $\begin{array}{l}1.72 \\
\pm \\
0.17 \mathrm{a} \\
\end{array}$ & $\begin{array}{l}0.77 \\
\pm \\
0.14 \mathrm{a}\end{array}$ & $\begin{array}{l}96.5 \\
\pm \\
14.1 \mathrm{a} \\
\end{array}$ \\
\hline 5 & 1.52 & $\begin{array}{l}27.2 \\
\pm \\
1.0 \mathrm{a} \\
\end{array}$ & $\begin{array}{l}9.55 \\
\pm \\
0.5 \mathrm{a} \\
\end{array}$ & $\begin{array}{l}4.4 \\
\pm \\
0.5 \mathrm{~b} \\
\end{array}$ & $\begin{array}{l}64.5 \\
\pm \\
4.5 \mathrm{~b}\end{array}$ & $\begin{array}{l}12.5 \\
\pm \\
1.5 \mathrm{~b} \\
\end{array}$ & $\begin{array}{l}1.5 \\
\pm \\
0.5 \mathrm{~b} \\
\end{array}$ & $\begin{array}{l}0.16 \\
\pm \\
0.04 \\
\end{array}$ & $\begin{array}{l}0.19 \\
\pm \\
0.06 \mathrm{c} \\
\end{array}$ & $\begin{array}{l}3.36 \\
\pm \\
1.1 \mathrm{~b} \\
\end{array}$ & $\begin{array}{l}0.31 \\
\pm \\
0.3 \mathrm{a} \\
\end{array}$ & $\begin{array}{l}2.6 \\
\pm \\
0.1 \mathrm{a} \\
\end{array}$ & $\begin{array}{l}380 \\
\pm \\
56 \mathrm{a} \\
\end{array}$ & $\begin{array}{l}505 \\
\pm \\
54 \mathrm{a} \\
\end{array}$ & $\begin{array}{l}1.74 \\
\pm \\
0.19 \mathrm{a} \\
\end{array}$ & $\begin{array}{l}0.76 \\
\pm \\
0.13 a\end{array}$ & $\begin{array}{l}96.5 \\
\pm \\
10.1 \mathrm{a} \\
\end{array}$ \\
\hline 6 & 1.77 & $\begin{array}{l}27.2 \\
\pm \\
0.6 \mathrm{a} \\
\end{array}$ & $\begin{array}{l}9.56 \\
\pm \\
0.5 \mathrm{a} \\
\end{array}$ & $\begin{array}{l}4.4 \\
\pm \\
0.4 \mathrm{~b} \\
\end{array}$ & $\begin{array}{l}65.1 \\
\pm \\
6.1 \mathrm{~b} \\
\end{array}$ & $\begin{array}{l}14.0 \\
\pm \\
1.5 \mathrm{~b} \\
\end{array}$ & $\begin{array}{l}1.6 \\
\pm \\
0.3 \mathrm{~b} \\
\end{array}$ & $\begin{array}{l}0.22 \\
\pm \\
0.05 \mathrm{c} \\
\end{array}$ & $\begin{array}{l}0.25 \\
\pm \\
0.06 \mathrm{c} \\
\end{array}$ & $\begin{array}{l}3.4 \\
\pm \\
1.16 \mathrm{~b} \\
\end{array}$ & $\begin{array}{l}3.0 \\
\pm \\
0.3 \mathrm{a} \\
\end{array}$ & $\begin{array}{l}2.7 \\
\pm \\
0.1 \mathrm{a} \\
\end{array}$ & $\begin{array}{l}385 \\
\pm \\
52 \mathrm{a} \\
\end{array}$ & $\begin{array}{l}495 \\
\pm \\
74 \mathrm{a} \\
\end{array}$ & $\begin{array}{l}1.76 \\
\pm \\
0.21 \mathrm{a} \\
\end{array}$ & $\begin{array}{l}0.75 \\
\pm \\
0.19 a\end{array}$ & $\begin{array}{l}99.5 \\
\pm \\
6.9 \mathrm{a} \\
\end{array}$ \\
\hline
\end{tabular}

Means in the same column followed by different letters are significantly different (Duncan s Multiple Range Test $\mathrm{P}<0.05$ ).

Temp. $=$ Temperature ${ }^{\circ} \mathrm{C}$, D.O =Dissolved Oxygen, Satura. = saturation\%, T.alk. = total alkalinity, T.H = total hardness, T.P = total phosphorus, O.P = ortho phosphate 
Table (3): Total annual means of some heavy metals in water samples of experimental ponds as ppm.

\begin{tabular}{|c|c|c|c|c|c|c|c|c|}
\hline Treat. & $\begin{array}{l}\text { Density } \\
\text { Fish/ } \mathrm{m}^{3}\end{array}$ & $\mathrm{Fe}$ & $\mathrm{Mn}$ & $\mathrm{Zn}$ & $\mathrm{Cu}$ & $\mathrm{Pb}$ & $\mathrm{Cd}$ & $\mathrm{Hg}$ \\
\hline 1 & 10.1 & $\begin{array}{l}0.5 \mathrm{~b} \\
\pm \\
0.04\end{array}$ & $\begin{array}{l}0.24 b \\
\pm \\
0.09\end{array}$ & $\begin{array}{l}0.22 b \\
\pm \\
0.02\end{array}$ & $\begin{array}{l}0.26 \mathrm{ab} \\
\pm \\
0.04\end{array}$ & $\begin{array}{l}0.14 \mathrm{~b} \\
\pm \\
0.02\end{array}$ & $\begin{array}{l}0.075 b \\
\pm \\
0.01\end{array}$ & $\begin{array}{l}0.094 \mathrm{a} \\
\pm \\
0.01\end{array}$ \\
\hline 2 & 14.1 & $\begin{array}{l}0.52 b \\
\pm \\
0.03\end{array}$ & $\begin{array}{l}0.24 \mathrm{~b} \\
\pm \\
0.09\end{array}$ & $\begin{array}{l}0.22 b \\
\pm \\
0.04\end{array}$ & $\begin{array}{l}0.24 b \\
\pm \\
0.06\end{array}$ & $\begin{array}{l}0.15 b \\
\pm \\
0.02\end{array}$ & $\begin{array}{l}0.074 b \\
\pm \\
0.007\end{array}$ & $\begin{array}{l}0.09 \mathrm{a} \\
\pm \\
0.01\end{array}$ \\
\hline 3 & 1.0 & $\begin{array}{l}0.62 \mathrm{a} \\
\pm \\
0.03\end{array}$ & $\begin{array}{l}0.32 \mathrm{a} \\
\pm \\
0.07\end{array}$ & $\begin{array}{l}0.28 \mathrm{a} \\
\pm \\
0.03\end{array}$ & $\begin{array}{l}0.31 \mathrm{a} \\
\pm \\
0.09\end{array}$ & $\begin{array}{l}0.21 a \\
\pm \\
0.03\end{array}$ & $\begin{array}{l}0.12 \mathrm{a} \\
\pm \\
0.02 \\
\end{array}$ & $\begin{array}{l}0.09 a \\
\pm \\
0.01\end{array}$ \\
\hline 4 & 1.268 & $\begin{array}{l}0.62 \mathrm{a} \\
\pm \\
0.03 \\
\end{array}$ & $\begin{array}{l}0.34 \mathrm{a} \\
\pm \\
0.06 \\
\end{array}$ & $\begin{array}{l}0.27 a \\
\pm \\
0.02 \\
\end{array}$ & $\begin{array}{l}0.3 a \\
\pm \\
0.07\end{array}$ & $\begin{array}{l}0.22 \mathrm{a} \\
\pm \\
0.03 \\
\end{array}$ & $\begin{array}{l}0.14 \mathrm{a} \\
\pm \\
0.022 \\
\end{array}$ & $\begin{array}{l}0.106 a \\
\pm \\
0.011\end{array}$ \\
\hline 5 & 1.52 & $\begin{array}{l}0.65 a \\
\pm \\
0.06\end{array}$ & $\begin{array}{l}0.33 a \\
\pm \\
0.07\end{array}$ & $\begin{array}{l}0.28 \mathrm{a} \\
\pm \\
0.03\end{array}$ & $\begin{array}{l}0.26 \mathrm{ab} \\
\pm \\
0.09\end{array}$ & $\begin{array}{l}0.24 a \\
\pm \\
0.04\end{array}$ & $\begin{array}{l}0.11 \mathrm{a} \\
\pm \\
0.04\end{array}$ & $\begin{array}{l}0.118 \mathrm{a} \\
\pm \\
0.021\end{array}$ \\
\hline 6 & 1.77 & $\begin{array}{l}0.64 a \\
\pm \\
0.05\end{array}$ & $\begin{array}{l}0.33 a \\
\pm \\
0.09\end{array}$ & $\begin{array}{l}0.26 a \\
\pm \\
0.05\end{array}$ & $\begin{array}{l}0.27 \mathrm{ab} \\
\pm \\
0.09\end{array}$ & $\begin{array}{l}0.23 a \\
\pm \\
0.04\end{array}$ & $\begin{array}{l}0.13 a \\
\pm \\
0.01\end{array}$ & $\begin{array}{l}0.107 a \\
\pm \\
0.034\end{array}$ \\
\hline
\end{tabular}

Means in the same column followed by different letters are significantly different (Duncan s Multiple Range Test $\mathrm{P}<0.05$ ). 
Table (4): Average concentrations of some heavy metals $(\mu \mathrm{g} / \mathrm{g})$ in liver, gills and muscles tissue for fishes species.

\begin{tabular}{|c|c|c|c|c|c|c|c|c|c|c|c|c|c|c|c|c|c|}
\hline \multirow{2}{*}{\multicolumn{2}{|c|}{ organs }} & \multicolumn{4}{|c|}{ Nile Tilapia } & \multicolumn{4}{|l|}{ Mullet } & \multicolumn{4}{|c|}{ Common Carp } & \multicolumn{4}{|c|}{ Silver Carp } \\
\hline & & $\mathrm{Fe}$ & $\mathrm{Zn}$ & Cd & $\mathrm{Pb}$ & $\mathrm{Fe}$ & Zn & Cd & $\mathrm{Pb}$ & $\mathrm{Fe}$ & $\mathrm{Zn}$ & Cd & $\mathrm{Pb}$ & $\mathrm{Fe}$ & $\mathrm{Zn}$ & Cd & $\mathrm{Pb}$ \\
\hline \multirow{3}{*}{1} & Liver & 110.24 & 170.56 & 6.46 & 72.82 & 111.65 & 172.46 & 6.78 & 74.42 & 110.76 & 171.08 & 6.58 & 72.96 & 105.46 & 160.42 & 5.72 & 70.06 \\
\hline & Gils & 62.8 & 40.2 & 5.54 & 60.2 & 64.06 & 40.56 & 6.02 & 61.08 & 63.12 & 40.44 & 5.54 & 60.92 & 60.72 & 36.76 & 5.12 & 54.98 \\
\hline & Muscle & 12.64 & 34.72 & 0.56 & 5.22 & 14.76 & 36.5 & 0.72 & 6.1 & 13.2 & 35.24 & 0.61 & 5.56 & 11.22 & 30.42 & 0.46 & 4.82 \\
\hline \multirow{3}{*}{2} & Liver & 115.86 & 176.12 & 6.92 & 75.06 & 116.66 & 176.7 & 6.96 & 75.01 & 115.02 & 172.96 & 6.96 & 73.09 & 109.06 & 162.92 & 5.96 & 70.7 \\
\hline & Gils & 66.1 & 44.16 & 5.7 & 62.08 & 66.7 & 44.22 & 6.19 & 62.0 & 65.62 & 42.06 & 5.88 & 61.14 & 61.92 & 37.22 & 5.7 & 55.19 \\
\hline & Muscle & 12.7 & 34.96 & 0.58 & 5.26 & 15.05 & 36.82 & 0.86 & 6.18 & 13.32 & 35.61 & 0.66 & 5.71 & 11.28 & 30.9 & 0.46 & 4.86 \\
\hline \multirow{3}{*}{3} & Liver & 92.8 & 155.0 & 5.72 & 70.62 & 93.42 & 156.12 & 5.86 & 71.04 & 92.96 & 155.46 & 5.86 & 70.9 & 90.92 & 142.12 & 4.56 & 66.6 \\
\hline & Gils & 54.2 & 35.1 & 4.9 & 58.92 & 54.68 & 35.26 & 4.96 & 59.42 & 54.46 & 35.2 & 4.92 & 59.04 & 50.06 & 32.22 & 4.5 & 52.62 \\
\hline & Muscle & 9.66 & 29.46 & 0.36 & 4.74 & 9.76 & 29.58 & 0.39 & 4.92 & 9.7 & 29.5 & 0.38 & 4.82 & 9.22 & 26.44 & 0.35 & 4.02 \\
\hline \multirow{3}{*}{4} & Liver & 100.04 & 155.06 & 5.66 & 71.02 & 100.92 & 155.72 & 5.74 & 71.46 & 99.92 & 156.52 & 5.84 & 71.76 & 95.72 & 144.42 & 4.72 & 67.44 \\
\hline & Gils & 56.72 & 36.62 & 4.9 & 59.66 & 56.96 & 37.32 & 5.24 & 60.24 & 56.42 & 36.78 & 5.16 & 59.82 & 50.92 & 33.2 & 4.62 & 53.0 \\
\hline & Muscle & 10.42 & 32.72 & 0.4 & 4.96 & 10.68 & 33.34 & 0.48 & 5.22 & 10.5 & 33.52 & 0.45 & 5.12 & 9.62 & 26.82 & 0.36 & 4.3 \\
\hline \multirow{3}{*}{5} & Liver & 101.42 & 157.75 & 5.78 & 70.7 & 101.94 & 159.02 & 6.02 & 71.04 & 101.24 & 158.42 & 5.96 & 70.96 & 96.45 & 146.9 & 5.12 & 68.4 \\
\hline & Gils & 57.06 & 38.8 & 4.96 & 59.06 & 57.64 & 38.98 & 5.2 & 60.16 & 57.46 & 38.92 & 5.1 & 59.56 & 52.46 & 34.4 & 4.72 & 53.26 \\
\hline & Muscle & 11.06 & 33.52 & 0.42 & 5.02 & 11.18 & 34.42 & 0.52 & 5.14 & 10.6 & 33.92 & 0.48 & 5.1 & 9.9 & 27.26 & 0.38 & 4.42 \\
\hline \multirow{3}{*}{6} & Liver & 105.2 & 160.22 & 6.01 & 71.18 & 106.14 & 160.92 & 6.42 & 71.48 & 105.7 & 160.44 & 6.22 & 71.22 & 100.72 & 150.96 & 5.42 & 69.12 \\
\hline & Gils & 59.2 & 39.24 & 5.12 & 59.92 & 59.76 & 39.46 & 5.32 & 60.12 & 59.3 & 39.46 & 5.24 & 60.02 & 54.62 & 35.02 & 4.88 & 54.02 \\
\hline & Muscle & 11.42 & 34.04 & 0.5 & 5.12 & 11.66 & 34.42 & 0.54 & 5.36 & 11.5 & 34.12 & 0.52 & 5.22 & 10.02 & 28.24 & 0.42 & 4.56 \\
\hline
\end{tabular}


Table (5): Average counts and identification of phytoplankton and zooplankton in the experimental ponds.

\begin{tabular}{|c|c|c|c|c|c|c|c|c|c|c|}
\hline \multirow{2}{*}{ Ytems } & \multicolumn{5}{|c|}{ Phytoplankton (org $\times 10 / \mathrm{L})$} & \multicolumn{5}{|c|}{ Zooplankton (org/L) } \\
\hline & Blue-Green & Green & Bacillaroph. & Cyanoph. & Total & Copep. & Cladocera & Rotifera & Ostracoda & Total \\
\hline 1 & 1056 & 876 & 538 & 112 & 2582 & 51 & 31 & 19 & 11 & 112 \\
\hline 2 & 872 & 672 & 356 & 78 & 1978 & 42 & 24 & 11 & 9 & 86 \\
\hline 3 & 4566 & 3250 & 1110 & 818 & 9744 & 197 & 190 & 94 & 51 & 532 \\
\hline 4 & 2976 & 2116 & 918 & 716 & 6726 & 136 & 117 & 88 & 45 & 386 \\
\hline 5 & 2578 & 1750 & 798 & 696 & 5822 & 124 & 92 & 69 & 41 & 326 \\
\hline 6 & 2096 & 1450 & 678 & 576 & 4800 & 105 & 81 & 57 & 35 & 278 \\
\hline
\end{tabular}

Bacillaroph.=Bacillarophyta , Cyanoph = Cyanophyta 
Table (6): Fish production and net production of experimental ponds.

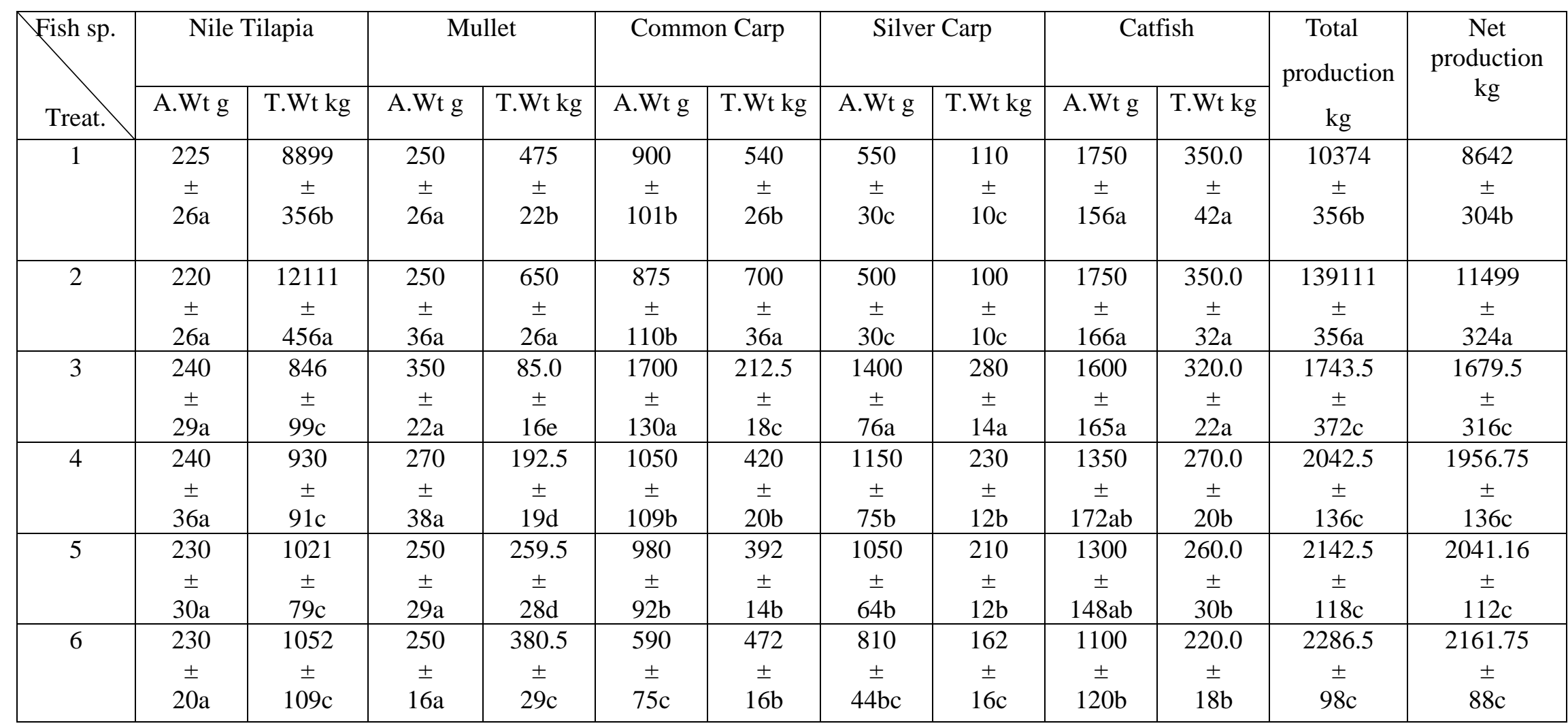

Means in the same column followed by different letters are significantly different $(\mathrm{P}<0.05)$. 
Table (7) : Growth performance of different fish species under different aquaculture systems on the experimental ponds.

\begin{tabular}{|c|c|c|c|c|c|c|c|c|c|c|c|c|c|c|c|}
\hline Items & \multicolumn{5}{|c|}{ Daily Gain } & \multicolumn{5}{|c|}{ Specific Growth Rate } & \multicolumn{5}{|c|}{ Condition factor } \\
\hline & $\begin{array}{c}\text { N.Tila } \\
\text { pia }\end{array}$ & Mullet & $\begin{array}{c}\text { C.Car } \\
\text { p }\end{array}$ & $\begin{array}{c}\text { S.Car } \\
\text { p }\end{array}$ & Catfish & $\begin{array}{l}\text { N.Tila } \\
\text { pia }\end{array}$ & $\begin{array}{c}\text { Mulle } \\
\mathrm{t}\end{array}$ & $\begin{array}{c}\text { C.Car } \\
\text { p }\end{array}$ & S.Carp & Catfish & N.Tilapia & Mullet & C.Carp & S.Carp & Catfish \\
\hline 1 & $\begin{array}{c}1.23 \\
\pm \\
0.14 \mathrm{a}\end{array}$ & $\begin{array}{l}1.47 \pm \\
0.11 \mathrm{~b}\end{array}$ & $\begin{array}{c}5.7 \\
\pm \\
0.24 \mathrm{~b}\end{array}$ & $\begin{array}{l}3.33 \pm \\
0.36 c\end{array}$ & $\begin{array}{c}11.47 \pm \\
1.92 \mathrm{a}\end{array}$ & $\begin{array}{c}1.15 \\
\pm \\
0.1 \mathrm{~b}\end{array}$ & $\begin{array}{c}1.41 \pm \\
0.1 c\end{array}$ & $\begin{array}{l}1.93 \pm \\
0.12 b\end{array}$ & $\begin{array}{c}1.59 \\
\pm \\
0.12 \mathrm{~b}\end{array}$ & $\begin{array}{c}2.37 \\
\pm \\
0.2 \mathrm{a}\end{array}$ & $\begin{array}{c}1.39 \\
\pm \\
0.2 \mathrm{a}\end{array}$ & $\begin{array}{c}1.2 \\
\pm \\
0.11 \mathrm{a}\end{array}$ & $\begin{array}{c}2.5 \\
\pm \\
0.15 a\end{array}$ & $\begin{array}{c}2.51 \\
\pm \\
0.14 \mathrm{a}\end{array}$ & $\begin{array}{c}2.57 \\
\pm \\
0.22 \mathrm{a}\end{array}$ \\
\hline 2 & $\begin{array}{c}1.2 \\
\pm \\
0.1 \mathrm{a}\end{array}$ & $\begin{array}{l}1.47 \pm \\
0.11 \mathrm{~b}\end{array}$ & $\begin{array}{c}5.5 \\
\pm \\
0.46 \mathrm{~b}\end{array}$ & $\begin{array}{c}3.0 \\
\pm \\
0.26 \mathrm{~b}\end{array}$ & $\begin{array}{c}11.47 \pm \\
1.56 \mathrm{a}\end{array}$ & $\begin{array}{c}1.14 \\
\pm \\
0.1 \mathrm{~b}\end{array}$ & $\begin{array}{c}1.41 \pm \\
0.1 \mathrm{c}\end{array}$ & $\begin{array}{l}1.91 \pm \\
0.16 \mathrm{~b}\end{array}$ & $\begin{array}{c}1.54 \\
\pm \\
0.12 \mathrm{~b}\end{array}$ & $\begin{array}{c}2.37 \\
\pm \\
0.22 \mathrm{a}\end{array}$ & $\begin{array}{c}1.56 \\
\pm \\
0.17 a\end{array}$ & $\begin{array}{c}1.22 \\
\pm \\
0.11 \mathrm{a}\end{array}$ & $\begin{array}{c}2.67 \\
\pm \\
0.15 a\end{array}$ & $\begin{array}{c}2.54 \\
\pm \\
0.12 \mathrm{a}\end{array}$ & $\begin{array}{c}2.67 \\
\pm \\
0.24 \mathrm{a}\end{array}$ \\
\hline 3 & $\begin{array}{c}1.53 \\
\pm \\
0.13 \mathrm{a}\end{array}$ & $\begin{array}{l}2.13 \pm \\
0.12 \mathrm{a}\end{array}$ & $\begin{array}{c}11.13 \\
\pm \\
1.1 \mathrm{a}\end{array}$ & $\begin{array}{c}9.0 \\
\pm \\
1.16 \mathrm{a}\end{array}$ & $\begin{array}{c}10.33 \pm \\
1.11 \mathrm{a}\end{array}$ & $\begin{array}{c}2.12 \\
\pm \\
0.12 \mathrm{a}\end{array}$ & $\begin{array}{c}1.64 \pm \\
0.1 \mathrm{a}\end{array}$ & $\begin{array}{l}2.69 \pm \\
0.17 \mathrm{a}\end{array}$ & $\begin{array}{c}2.22 \\
\pm \\
0.12 \mathrm{a}\end{array}$ & $\begin{array}{c}2.31 \\
\pm \\
0.17 a\end{array}$ & $\begin{array}{c}1.45 \\
\pm \\
0.14 \mathrm{a}\end{array}$ & $\begin{array}{c}1.3 \\
\pm \\
0.12 \mathrm{a}\end{array}$ & $\begin{array}{c}2.64 \\
\pm \\
0.12 \mathrm{a}\end{array}$ & $\begin{array}{c}2.76 \\
\pm \\
0.11 \mathrm{a}\end{array}$ & $\begin{array}{c}2.69 \\
\pm \\
0.21 \mathrm{a}\end{array}$ \\
\hline 4 & $\begin{array}{c}1.53 \\
\pm \\
0.15 \mathrm{a}\end{array}$ & $\begin{array}{c}1.6 \\
\pm \\
0.12 \mathrm{~b}\end{array}$ & $\begin{array}{c}6.8 \\
\pm \\
0.46 \mathrm{~b}\end{array}$ & $\begin{array}{l}7.47 \pm \\
0.46 \mathrm{~b}\end{array}$ & $\begin{array}{c}8.67 \\
\pm \\
1.1 \mathrm{~b}\end{array}$ & $\begin{array}{c}2.12 \\
\pm \\
0.12 \mathrm{a}\end{array}$ & $\begin{array}{c}1.47 \pm \\
0.1 \mathrm{~b}\end{array}$ & $\begin{array}{c}2.4 \\
\pm \\
0.17 a\end{array}$ & $\begin{array}{c}2.09 \\
\pm \\
0.4 \mathrm{a}\end{array}$ & $\begin{array}{c}2.19 \\
\pm \\
0.21 \mathrm{a}\end{array}$ & $\begin{array}{c}1.59 \\
\pm \\
0.12 \mathrm{a}\end{array}$ & $\begin{array}{c}1.2 \\
\pm \\
0.1 \mathrm{a}\end{array}$ & $\begin{array}{c}2.57 \\
\pm \\
0.14 a\end{array}$ & $\begin{array}{c}2.52 \\
\pm \\
0.32 \mathrm{a}\end{array}$ & $\begin{array}{c}2.46 \\
\pm \\
0.17 a\end{array}$ \\
\hline 5 & $\begin{array}{c}1.47 \\
\pm \\
0.14 \mathrm{a}\end{array}$ & $\begin{array}{l}1.47 \pm \\
0.12 \mathrm{~b}\end{array}$ & $\begin{array}{c}6.2 \\
\pm \\
0.76 \mathrm{~b}\end{array}$ & $\begin{array}{l}8.33 \pm \\
0.96 b\end{array}$ & $\begin{array}{c}8.33 \\
\pm \\
0.96 b\end{array}$ & $\begin{array}{c}2.09 \\
\pm \\
0.14 \mathrm{a}\end{array}$ & $\begin{array}{c}1.41 \pm \\
0.1 \mathrm{~b}\end{array}$ & $\begin{array}{l}2.33 \pm \\
0.17 \mathrm{a}\end{array}$ & $\begin{array}{c}2.03 \\
\pm \\
0.17 \mathrm{a}\end{array}$ & $\begin{array}{c}2.17 \\
\pm \\
0.17 a\end{array}$ & $\begin{array}{c}1.56 \\
\pm \\
0.13 a\end{array}$ & $\begin{array}{c}1.23 \\
\pm \\
0.1 \mathrm{a}\end{array}$ & $\begin{array}{c}2.62 \\
\pm \\
0.12 \mathrm{a}\end{array}$ & $\begin{array}{c}2.54 \\
\pm \\
0.24 \mathrm{a}\end{array}$ & $\begin{array}{c}2.57 \\
\pm \\
0.24 \mathrm{a}\end{array}$ \\
\hline 6 & $\begin{array}{c}1.47 \\
\pm \\
0.14 \mathrm{a}\end{array}$ & $\begin{array}{l}1.47 \pm \\
0.12 \mathrm{~b}\end{array}$ & $\begin{array}{l}5.07 \pm \\
0.39 b\end{array}$ & $\begin{array}{c}7.0 \\
\pm \\
0.79 b\end{array}$ & $\begin{array}{c}7.0 \\
\pm \\
0.79 \mathrm{~b}\end{array}$ & $\begin{array}{c}2.09 \\
\pm \\
0.15 \mathrm{a}\end{array}$ & $\begin{array}{c}1.41 \pm \\
0.1 \mathrm{~b}\end{array}$ & $\begin{array}{l}1.99 \pm \\
0.17 \mathrm{~b}\end{array}$ & $\begin{array}{c}1.99 \\
\pm \\
0.17 \mathrm{~b}\end{array}$ & $\begin{array}{c}2.06 \\
\pm \\
0.15 a\end{array}$ & $\begin{array}{c}1.56 \\
\pm \\
0.12 \mathrm{a}\end{array}$ & $\begin{array}{c}1.17 \\
\pm \\
0.1 \mathrm{a}\end{array}$ & $\begin{array}{c}3.12 \\
\pm \\
0.11 \mathrm{a}\end{array}$ & $\begin{array}{c}2.59 \\
\pm \\
0.26 \mathrm{a}\end{array}$ & $\begin{array}{c}2.57 \\
\pm \\
0.14 \mathrm{a}\end{array}$ \\
\hline
\end{tabular}

Means in the same column followed by different letters are significantly different $(\mathrm{P}<0.05)$. 
Table (8): Effect of production system on extensive and semi intensive fish culture.

\begin{tabular}{|c|c|c|}
\hline $\begin{array}{c}\text { treatments } \\
\text { Items }\end{array}$ & Extensive & Semi-intensive \\
\hline Stocking denisity/m ${ }^{3}$ & 1.39 & 12.1 \\
\hline Fish production & 2053.75 & 10070.5 \\
\hline Net production & 1959.79 & 2280 \\
\hline Total phytoplankton org/l & 6773 & 99 \\
\hline Total zooplankton & 380.5 & 22.92 \\
\hline Daily gain & 25.68 & 8.41 \\
\hline SGR & 10.17 & 10.4 \\
\hline Condition factors & 10.7 & 59579 \\
\hline Total costs & 6098.35 & 13071 \\
\hline Net return & 6028.9 & 4.865 \\
\hline Average cost/kg & 5.88 & 1.12 \\
\hline Return kg above T.V.C. LE & 2.94 & 123.3 \\
\hline Rate of return to capital \% & 200.73 & \\
\hline
\end{tabular}


Table(9): Economic efficiency for different for aquaculture system in earthen ponds.

\begin{tabular}{|c|c|c|c|c|c|c|c|c|c|c|c|c|}
\hline \multirow{2}{*}{ Items } & \multicolumn{2}{|c|}{ Treatment1 } & \multicolumn{2}{|c|}{ Treatment2 } & \multicolumn{2}{|c|}{ Treatment3 } & \multicolumn{2}{|c|}{ Treatment4 } & \multicolumn{2}{|c|}{ Treatment5 } & \multicolumn{2}{|c|}{ Treatment6 } \\
\hline & Quant & $\mathbf{L E}$ & Quant & LE & Quant & LE & Quant & $\mathbf{L E}$ & Quant & LE & Quant & LE \\
\hline T.1 ${ }^{\text {st }}$ class & 4741 & 33187 & 6259 & 43813 & 476 & 3332 & 546 & 3822 & 559 & 3913 & 570 & 3990 \\
\hline T. $2^{\text {nd }}$ class & 3072 & 15360 & 4079 & 20395 & 292 & 1460 & 306 & 1530 & 336 & 680 & 350 & 1750 \\
\hline T. $3^{\text {rd }}$ class & 966 & 3864 & 1346 & 5384 & 66 & 264 & 66 & 264 & 112 & 448 & 116 & 464 \\
\hline T. $4^{\text {th }}$ class & 120 & 240 & 427 & 854 & 12 & 24 & 12 & 24 & 14 & 28 & 16 & 32 \\
\hline M. $1^{\text {st }}$ class & 405 & 4860 & 521 & 6252 & 85 & 1020 & 170 & 2040 & 236.5 & 2838 & 296 & 3552 \\
\hline M. $2^{\text {nd }}$ class & 70 & 630 & 129 & 1161 & & & 25.5 & 202.5 & 23.0 & 207 & 84.5 & 760.5 \\
\hline C.C & 540 & 2160 & 700 & 2800 & 212.5 & 850 & 420 & 1680 & 392 & 1568 & 472 & 1888 \\
\hline S.C & 110 & 440 & 100 & 400 & 280 & 1120 & 230 & 920 & 210 & 840 & 162 & 648 \\
\hline CF & 350 & 1750 & 350 & 1750 & 320 & 1600 & 270 & 1350 & 260 & 1300 & 220 & 1100 \\
\hline Total prod. & 10374 & 62491 & 13911 & 82809 & 1743.5 & 9670 & 2042.5 & 11832.5 & 2142.5 & 12822 & 2286.5 & 14184.5 \\
\hline T. $40 \mathrm{~g}$ & 39.55 & 9887.5 & 55.05 & 13762.5 & $\mathbf{0}$ & $\mathbf{0}$ & $\mathbf{0}$ & $\mathbf{0}$ & $\mathbf{0}$ & 0 & 0 & $\mathbf{0}$ \\
\hline T. $10 \mathrm{~g}$ & $\mathbf{0}$ & $\mathbf{0}$ & $\mathbf{0}$ & $\mathbf{0}$ & 3525 & 352.5 & 3875 & 387.5 & 4434 & 443.4 & 4575 & 457.5 \\
\hline M. 50g & 2000 & 700 & 3000 & 1050 & $\mathbf{0}$ & $\mathbf{0}$ & $\mathbf{0}$ & $\mathbf{0}$ & 0 & $\mathbf{0}$ & 0 & $\mathbf{0}$ \\
\hline M. 20g & $\mathbf{0}$ & $\mathbf{0}$ & $\mathbf{0}$ & $\mathbf{0}$ & 250 & 62.5 & 750 & 187.5 & 1250 & 312.5 & 1750 & 437.5 \\
\hline CC $30 \mathrm{~g}$ & 600 & 60 & 800 & 80 & 125 & 12.5 & 400 & 40 & 400 & 40 & 800 & 80.0 \\
\hline SC $40 \mathrm{~g}$ & 200 & 20 & 200 & 20 & 200 & 20 & 200 & 20 & 200 & 20 & 200 & 20.0 \\
\hline Cf $100 \mathrm{~g}$ & 200 & 70 & 200 & 70 & 200 & 70 & 200 & 70 & 200 & 70 & 200 & 70.0 \\
\hline T. C.F & $\mathbf{0}$ & 10737.5 & & 14982.5 & & 517.5 & & 705 & & 885.9 & & 1065 \\
\hline Feed & 18.15 & 36300 & 27.6 & 55200 & 1.8 & 3600 & 2.4 & 4800 & 2.75 & 5500 & 3.0 & 6000 \\
\hline Manure & $\mathbf{0}$ & $\mathbf{0}$ & $\mathbf{0}$ & $\mathbf{0}$ & 1.2 & 60 & 1.2 & 60 & 1.2 & 60 & 1.2 & 60 \\
\hline Urea & $\mathbf{0}$ & $\mathbf{0}$ & $\mathbf{0}$ & $\mathbf{0}$ & 0.154 & 6.5 & 0.154 & 6.5 & 0.154 & 6.5 & 0.154 & 6.5 \\
\hline Superphos & $\mathbf{0}$ & $\mathbf{0}$ & $\mathbf{0}$ & $\mathbf{0}$ & 0.615 & 13.5 & 0.615 & 13.5 & 0.615 & 13.5 & 0.615 & 13.5 \\
\hline Aerator & $\mathbf{0}$ & 519 & $\mathbf{0}$ & 519 & $\mathbf{0}$ & $\mathbf{0}$ & $\mathbf{0}$ & $\mathbf{0}$ & $\mathbf{0}$ & $\mathbf{0}$ & $\mathbf{0}$ & $\mathbf{0}$ \\
\hline Labor & $\mathbf{0}$ & 250 & $\mathbf{0}$ & 250 & $\mathbf{0}$ & 50 & $\mathbf{0}$ & 50 & $\mathbf{0}$ & 50 & $\mathbf{0}$ & 50 \\
\hline T.V.C & $\mathbf{0}$ & 47806.5 & $\mathbf{0}$ & 70951.5 & $\mathbf{0}$ & 4247.5 & $\mathbf{0}$ & 5635 & $\mathbf{0}$ & 6515.9 & $\mathbf{0}$ & 7195 \\
\hline F. Cost & $\mathbf{0}$ & & $\mathbf{0}$ & $\mathbf{0}$ & $\mathbf{0}$ & $\mathbf{0}$ & $\mathbf{0}$ & $\mathbf{0}$ & $\mathbf{0}$ & $\mathbf{0}$ & $\mathbf{0}$ & $\mathbf{0}$ \\
\hline Dep. P. & $\mathbf{0}$ & 200 & $\mathbf{0}$ & 200 & $\mathbf{0}$ & 200 & $\mathbf{0}$ & 200 & $\mathbf{0}$ & 200 & $\mathbf{0}$ & 200 \\
\hline T. costs & $\mathbf{0}$ & 48006.5 & $\mathbf{0}$ & 71151.5 & $\mathbf{0}$ & 4447.5 & $\mathbf{0}$ & 5835 & $\mathbf{0}$ & 6715.9 & $\mathbf{0}$ & 7395 \\
\hline Net $R$. & $\mathbf{0}$ & 14484.5 & $\mathbf{0}$ & 11657.5 & $\mathbf{0}$ & 5222.5 & $\mathbf{0}$ & 5997.5 & $\mathbf{0}$ & 6106.1 & $\mathbf{0}$ & 6789.5 \\
\hline Av. C. & $\mathbf{0}$ & 462 & $\mathbf{0}$ & 511 & $\mathbf{0}$ & 255 & $\mathbf{0}$ & 286 & $\mathbf{0}$ & 313 & $\mathbf{0}$ & 323 \\
\hline Av. Pri. & $\mathbf{0}$ & 602 & $\mathbf{0}$ & 595 & $\mathbf{0}$ & 555 & $\mathbf{0}$ & 579 & 0 & 598 & 0 & 620 \\
\hline $\begin{array}{l}\text { R.A.T.V.C } \\
\text { (LE) }\end{array}$ & $\mathbf{0}$ & 140 & $\mathbf{0}$ & 84 & $\mathbf{0}$ & 300 & $\mathbf{0}$ & 293 & $\mathbf{0}$ & 285 & $\mathbf{0}$ & 297 \\
\hline RRC \% & $\mathbf{0}$ & 130.2 & $\mathbf{0}$ & 116.4 & $\mathbf{0}$ & 217.4 & $\mathbf{0}$ & 202.8 & $\mathbf{0}$ & 190.9 & $\mathbf{0}$ & 191.8 \\
\hline
\end{tabular}

F.Prod. - Fish production. $\quad$ C.C- Common carp $\quad$ S.C.- Silver Carp

- F.Prod. : Fish production .

- T. prod. : Total production.

- M. :Mullet.

- Net R. : Net return.
- C.C : Common Carp .

- V. costs : Variable costs.
- S.C : Silver Carp.

- Finger. : Fingerlings.

- Dep. P. : Deprecation pond.

- Av. Pri.: Average price.
- Cf : Catfish.

- T. : Tilapia.

- T. costs: Total cost

- R.abv.: Retun above. 